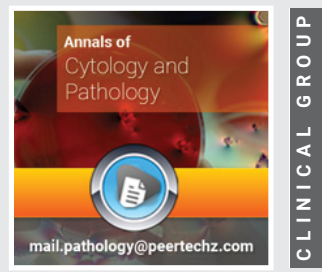

\title{
Some "Biological Nonsenses"
} from the position of the

\section{karyogamic theory of} carcinogenesis

\author{
Gogichadze GDK*, Gedenidze SG and Gogichadze TG \\ Medical Microbiologist, Molecular Biology and Parasitology, Tbilisi State Medical University, Georgia
}

Received: 15 November, 2019

Accepted: 29 June, 2020

Published: 30 June, 2020

*Corresponding author: Gogichadze GDK, Medical Microbiologist, Molecular Biology and Parasitology, Tbilisi State Medical University, Georgia, Tel: +995 5935480 50; E-mail: gogi_gogichadze@yahoo.com

ORCID: https://orcid.org/0000-0001-5355-0848

Keywords: Fatty acids; Carbohydrates; Karyogamic theory; Fusion; Carcinogenesis; Precancerous cell

https://www.peertechz.com

Check for updates

\begin{abstract}
Malignant transformation of the normal somatic cells into tumorous ones can be assisted by the very difference in their nature agents and factors: penetrating radiation of different nature, numerous chemical substances, some oncogenic and infectious viruses, some toxins, pharmacological agents, some kind of irritation and some non-carcinogenic substance. Probably, the above-numerated agents and factors start up some a common mechanism of the conversion of normal cells into transformed state. As shown, carcinogenic potencies of some fatty acids, carbohydrates, and even distilled water and saline may be explained from the standpoint of karyogamic theory of carcinogenesis. All above-mentioned substances may induce perforations of different volume of plasma membranes of somatic cells. This may premise for cells' fusion process. In result of perforations, total negative charge of plasma membranes decrease, and the somatic cells acquire the capability of contacts with each other, which upon coincidence of the perforated sites of these organoids, may serve as a prerequisite to fusion process.
\end{abstract}

\section{Introduction}

Malignant transformations of normal somatic cells into cancer ones can be assisted by the very difference in their nature agents and factors: penetrating radiation of different nature, numerous chemical carcinogens, some oncogenic and infectious viruses, some pharmacological agents, some kinds of irritations etc. The above-enumerated carcinogens are probably initiating some common mechanism of normal cells converting into the transformed state.

In experimental oncology number of examples are known on induction of malignant neoplasms in laboratory animals after inoculation of, at first sight, indifferent substances, such as some fatty acids, carbohydrates, saline, even distilled water etc. Same results were obtained after epidemiological research of some of these agents, e.g. on respect of dietary fats and carbohydrates.

Explanation of these strange facts by means of already existing different hypotheses and theories of carcinogenesis is impossible. In this article we make attempt to explain the essence of this occurrences by means of karyogamic theory of carcinogenesis [1-4].

\section{Induction of malignant tumors by some fatty acids}

The relationship of nutrition and cancer is not a new concern. Hoffman [5], suggested that excessive weight and high caloric intake might be at the root of the increased cancer incidence in the developing world [5]. Recent datum refers to the influence of a restricted diet on the incidence of radiation induced tumors and leukemia in rats and mice [6]. The incidence of developing malignant tumors in rats and mice of either sex, exposed to total body gamma irradiation, was reduced considerably.

During the period of rapid development of civilization, on a relatively short evolutionary scale of time, nourishment of humans underwent deep changes. Physiology of human being of Stone Age is in confrontation with the nourishment of the XX-XXI centuries. After industrialization of the society and growth of its economics; state ratio of dietary fats in human nourishment relatively increased in the form of meat and vegetable oils. 
Some aspects of fatty acid's interrelation with the process of carcinogenesis was in the scope of scientific view for a very long time. Correlation between consumption of dietary fats and development of breast cancer was first observed in the early 20 's of XX century. At the end of the 30's in scientific literature appeared a new data on carcinogenetic properties of several fatty acids after their overheating $[7,8]$. There are number of experimental data about an origin of malignant tumors in stomach and liver of mice and rats after feeding them overheated dietary fats for a long period of time. Similar results were obtained after feeding mice with cholesterol, turpentine, orange, eucalyptus and croton oils.

These kind of intensive experiments were conducted in recent years; they confirmed etiological role of dietary fats in producing malignant tumors of different histogenesis and localization, in particular, breast, colon and prostate cancers [9-11]. In laboratory animal based experiments it was demonstrated that high content of dietary fats in food $(40 \%$ of calories), stimulated development of breast cancer, while low content of dietary fats ( $10 \%$ of calories) did not reveal carcinogenic effect. At the same time it was demonstrated that polyunsaturated fatty acids increase process of carcinogenesis more intensively, than saturated fatty acids.

At the same time, some scientists report on fusogenic effect of different (but not all!) fatty acids in in vitro tissue culture [12-14]. In these scientific works numerous fatty acids were studied on their fusogenic properties. These scientists concluded that easiest fusion process occurs with unsaturated fatty acids.

The mechanism inducing malignant neoplasms in human by these substances is so far unknown. Explanation of this mechanism on the basis of such famous modern theories of carcinogenesis, as polyetiologic, virus-genetic, mutation, oncogenes an so on, is impossible. But parallelism between carcinogenicity and fusogenicity of these substances, allow us to consider this phenomenon as confirmation of somatic hybridization theories of carcinogenesis.

On the basis of world literature data and our own theoretical and experimental observations $[15,16]$ we attempt to explain the carcinogenicity of some dietary fats from the standpoint of hybridization theory of carcinogenesis (in particular, from karyogamic or two synkaryons theory).

In our experiments it was established that polyunsaturated (linoleic) and monounsaturated (oleic) fatty acids differ from saturated acids by the high intensity interaction with the cellular membranes. Especially high fusogenic activity has oleic acid. But by means of epidemiological analysis carcinogenic activity of this fatty acid was not established. What is the reason of this strange occurrence? Reverse correlation between fusogenic and carcinogenic abilities was revealed: higher is the fusogenic activity of this or that substance, lower is its' carcinogenic activity and vice versa. In particular, in case of high fusogenic ability of the substance (for example, oleic acid) formation of giant unviable polykaryocytes was induced and carcinogenic effect was less manifested; and vice versa, carcinogenic effect was higher in the presence of low fusogenic ability of the substance (for example, linoleic acid) because of formation of mainly dikaryons with high oncogenic potency $[15,16]$.

Some dietary fats may induce perforations of definite size of somatic cells in several conditions. This may be premise for cells' fusion and hetero- and homokaryon formation. Presumably, during the perforation of a cellular membranes, the total negative charge of plasma membranes decreases, and the somatic cells acquire the capability to approach closer (adhesion), which frequently, especially, upon coincidence of the perforated parts, may serve as a prerequisite to fusion process.

Prolonged action of some dietary fats (if they possess promoter abilities too) or full carcinogens and promoters on corresponding tissue (where precancerous cells preexist), induce arising of the first cancerous cell.

Thus, a tumorous cell is a result of fusion of two normal somatic cells after influence of certain carcinogenic (and noncarcinogenic) agents. Dikaryons (hetero- or homokaryons) are formed at the stage of initiation, and then after the reunion of nuclei form mononuclear, tetraploid (or subtetraploid) initiated cells, i.e. precancerous synkaryon. This cell exists in a macro organism for indefinetely long time. At the stage of promotion, after the full carcinogens or promoters influenced corresponding tissues (with preexistance of precancerous cells); intensity of cell's proliferation is induced. Precancerous cell after some conversions on a molecular and subcellular levels, may be transformed into the cancerous cell. From the chromosomal aberrations, the most dangerous in carcinogenic respect are imbalance translocations.

\section{Possible reason of induction of malignant tumors by some carbohydrates}

Population of so-called "developing" countries receive $80 \%$ of the calories from cereals, which consists of complex carbohydrates. After the industrialization of countries and development of their economics, the ration of population's part of fats rise considerably. At the same time consumption of refined sugar (simple carbohydrate) increases too. After such changes in nutrition; among the population occurrence of breast, colon and colorectal cancers rise.

On 1935 and 1938 Nishiyama, who studied carcinogenic properties of several chemical substances in rats, subcutaneously inoculated carbohydrates, in particular, glucose, together with certain substances (orthoaminoazotoluol). These experiments $[17,18]$ demonstrated that at the daily inoculation of $25 \%$ glucose solution $(1 \mathrm{~g} / \mathrm{kg})$, after more than 200 days in sites of injection polymorphocellular sarcomas were developed, in five cases out of seven. After increasing glucose concentrations number of malignant tumors were becoming higher and higher.

These experiments were continued by the studies of Takizawa [19]. This scientist subcutaneously inoculated into mice $25 \%$ glucose solution daily and day about. Spindle cell 
sarcomas aroused after 250 days in sites of injection in 5 mice out of 18 . Tumors formed by this way were passed to healthy mice. Tumors developed in mice and rats at long subcutaneous inoculation of other carbohydrates solutions as well. In this experiments in sites of injection of $25 \%$ fructose solution in 2 mice out of 16 developed sarcomas, but in site of inoculation of $25 \%$ galactose solution - in 4 mice out of 13 . In 1956 similar results were received by Azakawa [20]. On 1957 Takizawa Ooguchi and Hayashi observed development of sarcoma in 1 mice out 20 after the daily subcutaneous injection of $0,5 \mathrm{ml}$ of $25 \%$ of maltose solution [21].

Mettlin and Piver [22], Harlow and co-authors [23] by epidemiological analysis with case-control study established that milk consumption increased the risk of ovary cancer because of the lactose association to ovary failure. Moreover by epidemiologic analysis direct association were found between colorectal and breast cancers, as well as, intake of refined carbohydrates $[24,25]$.

It was reported that after the inoculation of chemical carcinogens in rats, rations of which was enriched by starch, breast tumors developed in considerably in less cases, than in animals ration of which was enriched by dextrose (the simple sugar) instead of starch.

The mechanism of influence of these classes of carbohydrates (dextrose, glucose, fructose, galactose et al) on the experimental carcinogenesis is yet unknown.

In scientific literature there are only few data on fusogenic action of several sugars. In 1917 Kalashnikov studied action of glucose solution on spawn of perch [26]. He observed giant cyncytiums in resting phase of dividing by means of amitosis. Author assumed that in some cases fusion of several nuclei into one does occur.

On 1992 Smeland and Funderud [27], reported about possible interrelation of the cellular adhesion, induced by sugar molecules, and the tumor etiology.

On 2005 we reported about fusogenic activity of glucose lactose, fructose, galactose, while starch did not reveal similar ability [16].

The above-mentioned correlation between fusogenic and carcinogenic properties of several carbohydrates may indicate that after the influence of glucose, galactose, fructose and maltose in Nishiyama's and Takizawa's experiments malignant tumors may arise by means of somatic cell fusion and further hybridization.

\section{Induction of malignant tumors by distilled water}

As was shown after experimental works of Warabioka $[28,29]$, Watanabe and his co-authors [30], the daily inoculation of distilled water into intraperitoneal cavity of rats, in some cases development of connective tissue malignant tumors - sarcomas, in particular, fibrosarcomas, maybe induced. For instance, in experiments of Watanabe, in 2 rats after daily inoculation of $3 \mathrm{ml}$ of distilled water, during 15-17 months fibrosarcomas were observed, which in one case was transplantable. Warabioka, in 13 months after daily injection of distilled water, in 1 rat observed sarcoma, which at lethal stage reached the size of a hen's egg. Inoculation of $1 \%, 1,5 \%$ or $2 \%$ aqueous solution of trypan blue injected subcutaneously in the Wistar or Sprague-Dawley rats $(0,5 \mathrm{ml}$ per $150 \mathrm{~g}$ body weight, fortnightly) induced production of hepatic sarcomas [30].

Interpretation of these results from the position of different theories and hypotheses of carcinogenesis, turn out to be impossible. For example, it is difficult to express, how distilled water can activate some endogenous viruses or induce expression of definite oncogenes with the following development of malignant neoplasms.

At first sight, it is complicated to explain these events from the position of karyogamic theory too, such as the fusogenic properties of distilled water is yet unknown.

Confirmation of the above-mentioned may be a data of Sokolov [31], in which at research of seminal glands of some insects, in particular, of Omocestus viridilus L., Chorthippus albomarginatus D.C. and Ch. Parallelus Zett., performed injection of distilled water. In result of this manipulation was revealed giant polynuclear cellular structures, formed after the fusion of normal cells and their nuclei. These giant cells, as a rule, are subject to degeneration.

On the other hand it is known, that in some conditions distilled water has the capability to induce destruction of somatic cells, in particular, erythrocytes plasma membranes, what is followed by the intensive hemolysis. This event, i.e. perforation of cells surface, in this particular case may be a cause of cellular membranes fusion process. As known, for isolate leukocyte layer (buffy coat) from the whole blood; used method of so-called "hypotonic shock" [32]. Essence of this method consists in addition of distilled water to the blood with anticoagulant substances, with ratio of $1: 1$, then shaking it up during 15 seconds. In this period of time intensive hemolysis will destruct absolute majority of erythrocytes and retain leukocytes plasma membranes or form in them perforations of little size (volume).

As was marked above, any fusogenic agents or factors may induce perforations of definite size or modifications of somatic cells plasma membranes with following fusion of these organoids. Perforations of big size induce considerable destroying of cytoplasmic membranes, cytolysis and perishing of the cells.

Proceeding from above-mentioned, we may make an assumption, that daily injection of distilled water into intraperitoneal cavity (or subcutaneously) of experimental animals, in some cases may induce perforations of different sizes of neighboring cells' plasma membranes, which sometimes assist their approach and following fusion process.

One may imagine, that in sites of inoculation (or near of this site), distilled water may induce in cellular plasma membranes perforations of big size, which from oncological point of view 
is not dangerous. And only in tissues localized little far from the site of inoculation create conditions, favorable for cells approach, their fusion, and following somatic hybridization with rising of precancerous cell.

Perishing of considerable quantity of somatic cells in result of plasma membranes destruction directly on site of injection, as known, may be favorable for the process of regeneration of corresponding tissue and intensive proliferation of cells (by production of "growth factor"). This in its' turn may involve the process of precancerous synkaryons proliferation too Precancerous cells after some processes on molecular and subcellular levels may be transformed into tumor synkaryons.

\section{Induction of malignant neoplasms by saline}

As it is known, several data of scientific literature testify carcinogenic action of saline (physiological solution) in experimental conditions. In 1940 Japanese scientist Tokoro reported on the development of reticulosarcoma and spindlecell sarcoma in the site of daily subcutaneous injection of $5-20 \%$ saline in two rats [33]. Malignant tumor in first rat developed after 97 injections, and in second rat - after 82 injections. Report of Tokoro so far is an only one (with the exception of data of J. Weisburger, E.Weisburger [34] and it is impossible to explain these facts by existing theories and hypotheses of carcinogenesis.

Explanation of this phenomenon by the karyogamic theory is also very complex, due to the lack of scientific data on fusogenic properties of this substance. Although, in 1917 Kalashnikov observed polynucleated giant syncytium in the resting phase and during division he acted on spawn of perch by physiologic solution [26]. The main cause of this process, to author's opinion, is amitosis and fusion of several nuclei.

As was shown in recent years, saline may, in several conditions, modify properties of cytoplasmic membranes' lipid bilayer. This occurrence may ultimately induce alterations of negative charge of somatic cell's surface, which may assist to near approach of cells and as a result - their fusion.

Parallelism between carcinogenic and fusogenic properties of physiological solution (although on the basis of single observations) allow us to assume the mechanism of its' action. Thus, this strange fact we may explain from standpoint of karyogamic theory of carcinogenesis.

\section{Conclusion}

Thus, in the experimental oncology there are number of examples on induction of malignant neoplasms in the laboratory animals after the inoculation, at first sight, of indifferent, noncarcinogenic substances, such as dietary fats, carbohydrates, distilled water, physiological solution and so on. It is possible that some dietary fats and carbohydrates too may induce perforations or modifications of somatic cells' plasma membranes in several conditions. These facts play the definite role in the process of fusion and in arising of the tumor cells. Distilled water and saline has capacity for destroying somatic cell's plasma membranes. Perforations of these organoids are the reason of cellular membranes' fusion. Daily injection of distilled water and saline into laboratory animals may induce perforations of plasma membranes of somatic cells, which assist their interaction, following a fusion process.

\section{References}

1. Hallion L (1907) Sur la pathogenie du cancer; theorie karyogamique. Press Med Par 10-11.

2. Gogichadze GK, Gogichadze TG (2010) Karyogamic Theory of Cancer Cell Formation from the View of the XXI Century. Nova Biomedical Books New York. Link: https://bit.ly/3eLIZGi

3. Gogichadze G (2016) Views and Suppositions about the Pathogenesis of Cancer. Hamburg, Dissera Verlag. Link: https://bit.ly/3dH57Pq

4. Gogichadze GK (2016) Searching for a magic key in oncology continues. In: Horizons in Cancer esearch. Editor: Hiroto S.Watanabe $61: 1-18$

5. Hoffman FL (1915) The Mortality from Cancer throughout the World. Newark Prudential Press.

6. Gross L (1988) Inhibition of the development of tumors or leukemia in mice and rats after reduction of food intake. Cancer 62 :1463-1465. Link: https://bit.ly/3g5m1ca

7. Roffo $\mathrm{AH}$ (1938) Accion cancerigena de los derivados fenantrenicos de cholesterol. Bol Inst De Med Exper Para el Estud y Trat d Cancer 15: 837-845.

8. Beck S (1941) Sarcoma produce by subcutaneous injections of overheated cotton-seed oil into mice. Brit J Exper Pathol 22: 299-302. Link: https://bit.ly/2ZjvKor

9. Cohen LA, Thompson DO, Maeura Y (1986) Dietary fat and mammary cancer. I.Promoting effect of different dietary fats on $\mathrm{N}$-nitrosomethylureainduced rat mammary tumorigenesis. J Natl Cancer Inst 77: 33-42. Link: https://bit.ly/2CK5TOQ

10. Freedman LS, Clifford C, Messina M (1990) Analysis of dietary fat, calories, body weight, and the development of mammary tumors in rats and mice: a review. Cancer Res 50: 5710- 5719. Link: https://bit.ly/2ZhBPSI

11. Rao CV, Hirose Y, Indranie C, Reddy BS (2001) Modulation of experimenta colon tumorigenesis by types and amounts of dietary fatty acids. Cancer Res 61: 1927-1933. Link: https://bit.ly/3iiyf3h

12. Lucy JA, Ahkong QF, Cramp FC, Fisher D, Howell JI (1971) Cell fusion without viruses. Biochem J 124: 46-47. Link: https://bit.ly/31tsGZA

13. Ahkong QF, Cramp FC, Fischer D, Howell JI, Lucy JA (1972) Studies on chemically induced cell fusion. J Cell Science 10: 769-787. Link: https://bit.ly/3g6XJ1n

14. Ahkong QF, Fischer D, Tampion W, Lucy JA (1973) The fusion of erythrocytes by fatty acids, retinol and alpha-tocopherol. Biochem J 136: 147-155. Link: https://bit.ly/3dFjMe8

15. Gogichadze G, Beniashvili D, Piriashvili V (1994) Some aspects of interaction of dietary fats and carcinogenesis. Proc Acad Sciences of Georgia 20: 69-74

16. Gogichadze GK, Gogichadze TG (2005) Cancer as a result of somatic cells fusion caused by some dietary fats and carbohydrates. Med Hypotheses 65 : 622-623. Link: https://bit.ly/31rtoqc

17. Nishiyama $Y$ (1935) Experimentalle hepatombildung durch futterung mit 0-aminoazotoluol beimaus. Gann 29: 285-294.

18. Nishiyama $Y$ (1938) Experimentalle erzeugung des sarkoms bei ratten durch wiered-holte injec-tionen von glucoselosung. Gann 32: 85-98. 
19. Takizawa N (1940) Experimentalle erzeugung des sarkoms bei der maus durch die injection von glucose, fructose und galactose. Ein beitrag zur frage der histogenese des fibroplastischelen sarcoma. Gann 34: 1-5.

20. Azakawa S (1956) Experimental production of sarcoma of mice with the subcutaneous high con- centrated sugar solution, especially lactose, and mixture of laevulose and glucose. Gann 47: 592-593.

21. Takizawa N, Ooguchi H, Hayashi J (1957) Experimental production of sarcoma in mice with ad- ministration of reducing saccharides, especially maltose effects of adenosine triphosphate on the sarcomatous proliferation of fibroblasts induced by injection of reducing saccharides. Gann 48: 556-558.

22. Mettlin CJ., Piver MS (1990) A case-control study of milk drinking and ovarian cancer risk. Am J Epidemiol 132: 871-876. Link: https://bit.ly/3eMWu7m

23. Harlow BL, Craemer DW, Geller J (1991) The influence of lactose consumption on the association of oral contraceptive use and ovarian cancer risk. Am J Epidemiol 134: 445-453. Link: https://bit.ly/2BKpSN4

24. Key TG (2001) Glycemic index, hyperinsulinemia, and breast cancer risk. Ann Oncol 12: 1507-1509. Link: https://bit.ly/3eJPEPR

25. Hassan AB, Macaulay VM (2002) The insulin-like growth factor system as a therapeutic target in colorectal cancer. Ann Oncol 13: 349-356. Link: https://bit.ly/2ZjXDN3

26. Kalashnikov PP (1917) Observations over development of eggs of Perca fluviatilis in artificial solutions. Works of Soc Natural Scientists of Petrograd XLV-LII.
27. Smeland EB, Funderud S (1992) Sugar molecules, cell adhesion and cancer etiology. Tidsskrift Nor Laegeforen 112: 2834. Link: https://bit.ly/2NFnEBi

28. Warabioka K (1956) On the experimentally induced subcutaneous sarcoma in the rat following repeated topical injections of aqua gelida. Gann 47: 603-606. Link: https://bit.ly/2Zn9Xfw

29. Warabioka K (1957) On the induction of sarcoma in rats injected with aqua distillata gelida II. Second report Gann 48: 577-579. Link: https://bit.ly/3dHupwX

30. Watanabe T, Ibata H, Sugikoto T, Azuma S, Yasuoka M, et al. (1957) Production and inhibition of hepatic sarcomata in rats by injections of trypan blue. Gann 48: 576-577. Link: https://bit.ly/3dGO4NE

31. Sokolov II (1955) About fusion of cellular nuclei. Arch Anat Histol Embriol 54 62.

32. Evans WH, Wolf MM, Chabner TA (1974) Concentration of immature and mature granulocytes from normal human born marrow. Proc Soc Exp Biol Med 146: 526-529. Link: https://bit.ly/3dE1Lgh

33. Tokoro Y (1940) Uber die artificielle erzeugung des sarkoms bei den weissen ratten mittels konzentrierte Kochsalzlosun. Gann 34: 149-155.

34. Weisburger JH, Weisburger EK (1969) Chemical substances as reason of cancer. Usp.V IzucheniRaka VIII: 501-539.
Discover a bigger Impact and Visibility of your article publication with Peertechz Publications

\section{Highlights}

* Signatory publisher of ORCID

* Signatory Publisher of DORA (San Francisco Declaration on Research Assessment)

* Articles archived in worlds' renowned service providers such as Portico, CNKI, AGRIS, TDNet, Base (Bielefeld University Library), CrossRef, Scilit, J-Gate etc.

* Journals indexed in ICMJE, SHERPA/ROMEO, Google Scholar etc.

* OAI-PMH (Open Archives Initiative Protocol for Metadata Harvesting)

* Dedicated Editorial Board for every journa

* Accurate and rapid peer-review process

* Increased citations of published articles through promotions

* Reduced timeline for article publication

Submit your articles and experience a new surge in publication services (https://www.peertechz.com/submission).

Peertechz journals wishes everlasting success in your every endeavours.

Copyright: (C) 2020 Gogichadze GDK, et al. This is an open-access article distributed under the terms of the Creative Commons Attribution License, which permits unrestricted use, distribution, and reproduction in any medium, provided the original author and source are credited. 